\title{
Behavior Change Therapy Model for Improving Tooth Brushing Behavior among Children with Mental Retardation
}

\author{
Rohisotul Laily;Rasipin²; Supriyana3;'Suharyo Hadisaputro; Bedjo Santoso5 \\ ${ }^{1}$ Master of Applied Dental Health Therapist Health Ministry of Health Polytechnic Semarang \\ 2,3,4,5 Lecture Health Ministry of Health Polytechnic Semarang
}

\section{Article info}

\section{Article history:}

Received; July $10^{\text {th }}, 2020$

Revised: August $03^{\text {th }}, 2020$

Accepted: September $02^{\text {nd }}, 2020$

\section{Correspondence author:}

Rohisotul Laily

E-mail: rohisotullaily21@gmail.com

\section{DOI:}

http://doi.org.10.35654/ijnhs.v3i6.354

\begin{abstract}
Dental health problems occur in many communities, including mental retardation in children with all of their intellectual limitations, social behavior, and sometimes the weakness in motor coordination. The study aimed to develop and to examine the effectiveness of the behavior change therapy model as an alternative to improving the tooth brushing behavior among children with mental retardation. The Research and Development (R\&D) approach was applied in this study. The quasi-Experimental, Pre-test, and Post-test with the non-equivalent control group for examining the effect of the model on health outcome. The research subjects of mental retardation children were divided into the intervention group and the control group. Experts tested by the intervention group validated the model development. Expert validation of the behavior change therapy model gets an average of 86.67 (very decent) as an alternative to improving tooth brushing behavior among children with mental retardation with $\mathrm{p}$ value $<0.05$. Other results found that the model effectively enhanced the knowledge, gesture, and tooth brushing skills in mental retardation children with $\mathrm{p}$-value $<0.05$. The therapy model as an alternative strategy was useful and recommended improving tooth brushing behavior among mental retardation children.
\end{abstract}

Keyword: mental retardation, children, behavior change therapy model, tooth brushing. 



\section{INTRODUCTION}

In 2016, the World Health Organization (WHO) stated that 90\% of school-age children worldwide got dental caries (1). In 2018, Riset Kesehatan Dasar showed that 57.6\% of Indonesian people have oral and dental health problems (2). This is still far from Indonesia's caries-free national target in 2030 (3).

According to Badan Pendidikan dan Penelitian Kesejahteraan Sosial (Badiklit Kesos), in 2012, the population of people with severe disabilities in Indonesia totaled 3.342 .303 people, with the percentage of mental retardation children as much as $13.68 \%(290.837$ children) (4). Dental health problems also occur in children with mental retardation in Indonesia, particularly in Semarang by Saptiwi and Triyatno 2015 stated that the dental and oral hygiene (OHIS) rate reached $97.4 \%$ in the medium category in Semarang SLBN and $73.37 \%$ in the medium category in Widiasih Parigi $\operatorname{SLBN}(5,6)$.

The tooth and mouth disease was associated with plaque accumulation in the oral cavity. The plaque will begin to form quickly when we do not brush the teeth. However, efforts to reduce the accumulation of plaque in contact with the tooth surface must still be made to prevent the occurrence of the tooth cavity (7). In addition to internal factors, there are also external factors in dental disease, which are the tooth brushing behavior in mental retardation children, which tends to be unfavorable.

The impact of children with dental disease will inhibit the growth and development of the children themselves, such as the intellectual level of children decreases if it occurs continuously for an extended period. This is because the children get permission from school more often because of health problems (8).

Mental retardation children are classified into three categories: debil, embicil, and idiot (9). This is following the level of ability possessed. The children often experience intellectual, behavioral and social weaknesses, sometimes even mental retardation children have an imbalance in motor movement coordination like they can not hold their saliva, so they do require oral exercise to overcome them (10-12).

The needs of children with mental retardation are very diverse, so they need the participation of teachers and parents to teach about tooth brushing, which is a maintenance effort. Parental participation influences the behavior of children. The children will follow the behavior of parents who applied at home (13). Cooperation from various parties can improve optimal dental health in children with mental retardation (14). The ability to brush teeth properly and thoroughly is an activity that is difficult for normal children to do (15). Collaborative learning methods between teamwork and the involvement of other components greatly influence learning success (16).

The delivery method must be adapted to the tools or supporting media for the delivery (17). The influential media should utilize more of the senses used to record information so that the greater the possibility of understanding the information conveyed ${ }^{(18) .}$ ADA recommends therapy principles in mental retardation children where "play is a way of learning for children and an outlet for the innate needs of their activities" (15).

The model used to introduce ways to brush teeth correctly and adequately is the child's first step to improve tooth brushing behavior, so one effort is needed to innovate in the tooth brushing program. Based on these problems, research needs to be done to enhance tooth brushing. It is often possible to produce innovations as an alternative to solving problems.

\section{OBJECTIVE}

The study aimed to develop and examine the behavior change therapy model to improve tooth brushing behavior among children with mental retardation.

\section{RESEARCH METHODS}

The Research and Development (R\&D) was applied in this study to develop a behavior change therapy model. The main steps of the research and development procedure 
consisted of five stages: 1) information gathering, 2) designing and building models, 3) Expert validation and revision, 4) testing the modules, and 5) creating the final results of the model. Sixteen instruments of children's mental retardation, including knowledge, attitudes, and skills about tooth brushing behaviors, were used in this study.

Information gathering identifies and analyzes problems experienced by mental retardation children about dental health through qualitative descriptive methods with observation and interviews with the Health Office, Education Office, Head of primary health care, School Principals, Psychologists, Dental Nurses, parents, and teachers.

Data from information gathering is used as a basis for the development of models that will be applied to mental retardation children tailored to the needs and abilities of children.

The validation test is used to test the product's feasibility before it is applied to the target. Three experts tested the validation stage in health promotion, psychologists, and outstanding education experts. Experts play a role in testing models that have been designed before they are applied to mental retardation children. Data collection techniques using a questionnaire, then make revisions. Testing is done to produce a model that is suitable for the application.

Product trials are applied directly to the target. The design used was a quasiexperiment (pre-test and post-test with control group design) with 32 children with mental retardation divided into two, namely 16 in each group.

The purpose of this study is to develop methods of learning dental health in children with mental retardation. The statistical test of research data in the expert validation stage uses intra-class correlation. Simultaneously, in the testing phase in the control and intervention groups, the data is paired if the data are normally distributed using the repeated measure ANOVA test and the independent t-test.

\section{MODEL DEVELOPMENT}

\section{Information Collection}

Mental retardation children with the characteristics need an alternative program in behavior change in brushing their teeth repeatedly and providing education, practice, and requires the role of parental assistance. Parents need training of dental health workers in delivering correct education for children related to brushing their teeth.

\section{Design and construct the model}

The information from samples was used to design and develop learning methods, and alternative tooth brushing behavior changes, a behavior change therapy model in tooth brushing in children with mental retardation. This model has two different application lines that are tailored to the needs and abilities of the children. The activity phase starts from I. Assessment (assess the child's start in the academic, behavioral, and motoric fields), II. Goal Setting (determining the goals and strategies that will be applied to the children), III. Implementation (actions to be taken using the PECS approach and oral exercise among children in need), and IV. Evaluation (assess the achievement of actions taken).

\section{Expert validation}

This validation is carried out to obtain data used as a basis for testing the feasibility of the model. Expert validation results show that the value is $0.001(p<0.05)$ means that the behavior change therapy model is appropriate as a model of dental health education in children with mental retardation. 
Table.1 Expert validation of the model

\begin{tabular}{lcccc}
\hline \multicolumn{1}{c}{ Examiner } & Score & Average & Category & $\begin{array}{c}\text { P- } \\
\text { Value }\end{array}$ \\
\hline Examiner I & 87.27 & & Very decent & 0.001 \\
\hline Examiner II & 94.55 & 86.67 & & \\
\hline Examiner III & 78.18 & & &
\end{tabular}

\section{Testing model}

This study aims to examine the effectiveness of the model of behavior change therapy to improve children's knowledge, attitudes, and skills of mental retardation. Efforts to determine the effectiveness of the model then carried out the testing of two different groups. The first group was treated with a behavior change therapy model brushing their teeth, and the second group treated the dental health program at school. Respondents in this study were 32 mentally disabled children.

Table 2. Parental characteristics

\begin{tabular}{|c|c|c|c|c|c|c|}
\hline \multirow{3}{*}{ No } & \multirow{3}{*}{ Characteristics } & \multicolumn{4}{|c|}{ Group } & \multirow{3}{*}{ P-Value } \\
\hline & & \multicolumn{2}{|c|}{ Intervention } & \multicolumn{2}{|c|}{ Control } & \\
\hline & & $\mathrm{N}$ & $\%$ & $\mathrm{~N}$ & $\%$ & \\
\hline \multirow[t]{3}{*}{1} & Age & & & & & \\
\hline & $<9$ years & 11 & 35.5 & 9 & 29 & $1.000 *$ \\
\hline & $>9$ years & 4 & 12.9 & 7 & 22.6 & \\
\hline \multirow[t]{3}{*}{2} & IQ & & & & & \\
\hline & Mild & 8 & 25 & 8 & 25 & $0.337 *$ \\
\hline & Moderate & 8 & 25 & 8 & 25 & \\
\hline \multirow[t]{3}{*}{3} & Gender & & & & & \\
\hline & Male & 6 & 18.8 & 8 & 25 & $0.492 *$ \\
\hline & Female & 10 & 31.3 & 8 & 25 & \\
\hline
\end{tabular}

Table 2 shows that the age of children with mental retardation. The majority of the intervention and control groups are $<9$ years, Intelligence Quotient (IQ) of mental retardation children have the same proportion. The different test results show a $p$-value $>0.05$, so it can be concluded that the age and IQ of the children have the same variant. The gender of mental retardation children in the majority is women. Different test results show that the pvalue $>0.05$, so it can be concluded that the gender of mental retardation children has no significant difference.

This study examines the behavior change therapy model's effectiveness in improving the knowledge, attitudes, and skills in tooth brushing for mental retardation children. 
Table 3. Testing of normality data of mental retardation among children

\begin{tabular}{lcc}
\hline \multicolumn{1}{c}{ Variables } & \multicolumn{2}{c}{ P-value } \\
\cline { 2 - 3 } & Intervention & Control \\
\hline Pre-test of knowledge & 0.050 & 0.164 \\
Post-test 1 of knowledge & 0.002 & 0.044 \\
Post-test 2 of knowledge & 0.004 & 0.003 \\
Pre-test of Attitude & 0.145 & 0.070 \\
Post-test 1 Attitude & 0.231 & 0.064 \\
Post-test 2 Attitude & 0.022 & 0.241 \\
Pre-test of skills & 0.322 & 0.179 \\
Post-test 1 of Skills & 0.038 & 0.278 \\
Post-test 2 of Skills & 0.044 & 0.946 \\
\hline
\end{tabular}

*Shapiro-Wilk

Normality test results of knowledge, attitudes, and skills in tooth brushing of children with mental retardation are mostly normal because the p-value $>0.05$ can be continued with parametric statistical tests.

\section{Final model}

In the form of a module of behavior change therapy model of tooth brushing in children with mental retardation, the product in the form of a module of behavior change therapy model is the output of development of learning models to tooth brushing in children with mental retardation.

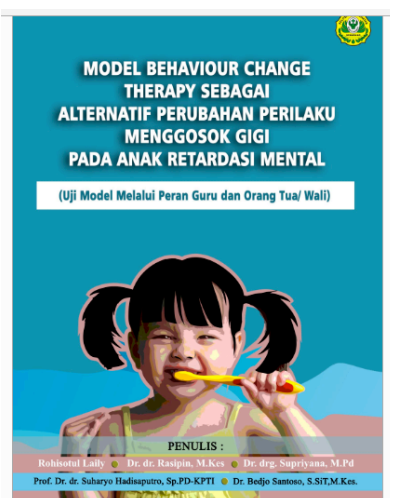

Figure 1. output of behavior change therapy model

\section{RESULTS}

\section{Effectiveness of model behavior change therapy on tooth brushing among children with mental retardation before and after receiving the intervention}

The effectiveness test results show that the p-value of the intervention group is 0.000 $(p<0.05)$. It means the behavior change therapy model of tooth brushing in children with mental retardation increased the knowledge, attitudes, and skills of parents/guardians. The control group's $p$-value is knowledge $(p=0.104)$, attitudes $(p=0.110)$, and skills $(p=0.120)$, which means $(p>0.05)$, means that the model of the school program does not effectively improve the knowledge, attitudes, and skills of parents/guardians of children with mental retardation. 
Table 4. Effectiveness of model behavior change therapy on tooth brushing among children with mental retardation before and after receiving the intervention

\begin{tabular}{lcccc}
\hline \multicolumn{1}{c}{ Group Variables } & $\begin{array}{c}\text { Mean } \pm \text { SD } \\
\text { Pre-test }\end{array}$ & $\begin{array}{c}\text { Mean } \pm \text { SD } \\
\text { Post-test1 }\end{array}$ & $\begin{array}{c}\text { Mean } \pm \text { SD } \\
\text { Post-test2 }\end{array}$ & P-value \\
\hline Knowledge & & & & \\
\hline Intervention & $5.31 \pm 1,014$ & $8.19 \pm 0.834$ & $8.88 \pm 0.719$ & 0.000 \\
Control & $5.25 \pm 1.065$ & $5.75 \pm 0.856$ & $5.31 \pm 0.704$ & 0.104 \\
\hline Attitude & & & & \\
\hline Intervention & $21.06 \pm 2.568$ & $25.31 \pm 1.448$ & $27.25 \pm 2.595$ & 0.000 \\
Control & $21.25 \pm 2.017$ & $21.06 \pm 1.914$ & $20.81 \pm 1.834$ & 0.110 \\
\hline Skills & & & & \\
\hline Intervention & $57.75 \pm 5.972$ & $68.88 \pm 4.241$ & $71.13 \pm 3.575$ & 0.000 \\
Control & $58,69 \pm 6,897$ & $60.19 \pm 5.868$ & $59.38 \pm 5.920$ & 0.120 \\
\hline
\end{tabular}

*repeated Measure Annova

The test results of the unpaired effectiveness of the change value $(\Delta)$ pretest-posttest1, posttest1-posttest2, and pre-posttest2. The findings showed the behavior change therapy model of a tooth significantly brushing in children with mental retardation effectively increased children's knowledge, attitudes, and mental retardation skills compared to the usual dental health program model.

\section{Effectiveness test of unpaired data $(\Delta)$ in behavior change therapy model of tooth brushing in children with mental retardation between the intervention group and the control group}

The test results of the unpaired effectiveness of the change value $(\Delta)$ pretest-posttest1, posttest1-posttest2, and pre-posttest 2 . The findings showed a significant behavior change therapy model of tooth brushing in children with mental retardation effectively in increasing children's knowledge, attitudes, and skills with mental retardation compared to the usual dental health program model at school.

Table 5. Effectiveness test of unpaired data $(\Delta)$ in behavior change therapy model of tooth brushing in children with mental retardation between the intervention group and the control group

\begin{tabular}{lccc}
\hline \multicolumn{1}{c}{ Variables } & \multicolumn{2}{c}{ Mean \pm SD } & P-value* \\
\cline { 2 - 4 } Knowledge & Intervention & Control & \\
pre-post1 & $2.88 \pm 0.719$ & $3.56 \pm 0.892$ & 0.000 \\
pre-post 2 & $0.69 \pm 0.793$ & $-0.44 \pm 0.892$ & 0.001 \\
post1- post & $3.56 \pm 0.892$ & $0.06 \pm 0.998$ & 0.000 \\
Attitude & & & \\
pre-post1 & $4.25 \pm 1.438$ & $-0.19 \pm 0.403$ & 0.000 \\
pre-post 2 & $1.92 \pm 2.542$ & $-0.25 \pm 0.856$ & 0.003 \\
post1- post & $6.19 \pm 3.291$ & $-0.44 \pm 0.892$ & 0.000 \\
Skill & & & \\
Pre-post1 & $1.13 \pm 3.519$ & $1.50 \pm 2.852$ & 0.000 \\
Pre-post2 & $2.25 \pm 1.807$ & $-0.81 \pm 1.834$ & 0.000 \\
Post-post2 & $3.38 \pm 4.319$ & $0.69 \pm 2.626$ & 0.000 \\
\hline
\end{tabular}

*Independent t-test 


\section{DISCUSSION}

The results of information collection concluded that mental retardation children's behavior in tooth brushing required efforts to provide education with the fit and appropriate methods and supported by learning media that can attract the children's attention so that the children can carry it out (17). Expert validation results show that the p-value is 0.000 , which means that the behavior change therapy model of tooth brushing in children with mental retardation is relevant as a model of dental health education program in children with mental retardation. Expert validation is essential to assess the appropriateness of the basic concepts and theories used in a product/model.

The model trials in this study were conducted on 32 people. The frequency of gender of mental retardation children is equal between boys and girls. This is in line with Ramayuni (2014) research in SLB Bukittinggi City, which stated that the number of mentally disabled sufferers is the same between women and men. The age between the two groups is spread evenly (18). However, this research is inversely proportional to a study conducted by Kurniawan (2017), which states that the frequency of mental retardation in boys is 1.5 times more than in girls (19).

The paired results showed that the p-value of the intervention group was $p<0.05$, which means the behavior change therapy model of tooth brushing in children with mental retardation effectively increases children's knowledge, attitudes, and skills tooth brushing.

The behavior change therapy model was effective in increasing knowledge, attitudes, and skills to brush teeth. Furthermore, index debris' value was carried out for ten days consisting of the first stage of the assessment, where there's an assessment for knowledge, attitudes, and behavior to the children's needs. The second stage is goal setting. Initial assessment results could evaluate the determination of the activities' purpose for children.

The third stage is carried out at the fourth to the tenth meeting, which is the implementation. Implementation of activities carried out on children as needed using visual media (pictorial) in its delivery and games included in activities that can make tooth brushing a fun activity to involve the children. Implementation activities carried out during six meetings. It was consistent with the previous study that stated that repetitive training would improve skills among children with special needs (20), and oral exercise was needed to conduct for all organs in the oral $(11,12)$. The fourth stage was evaluating the activities that have been carried out and seeing the activities' results.

The success of the behavior change therapy model of tooth brushing in children with mental retardation is seen from a decrease in the debris index value. The paired data effectiveness test results show that the p-value is $0.000(\mathrm{p}<0.05)$, which means that this model effectively decreases the index debris value. This debris score has dropped because the sample has been taught to understand how to brush teeth correctly. Proper brushing practices can improve oral hygiene. This is in line with research conducted by Liu (2014) (21).

\section{CONCLUSION}

Based on the study results, it can be concluded that the behavior change therapy model is feasible, and its application is useful as an effort to improve the behavior of brushing children's teeth in mental retardation. It is hoped that this model can be used as a program for children. Therefore, the creation of good tooth brushing behavior in children, and this model can be used as a particular program to improve tooth brushing behavior in children with mental retardation.

\section{References}

(1) World Health Organization (WHO). Oral Health Surveys: Basic Methods: World Health Organization; 2013. 
(2) Kementrian Kesehatan. Laporan Nasional Riset Kesehatan Dasar (Riskesdas) 2018. Jakarta 2018.

(3) Kementrian Kesehatan. Rencana Aksi Nasional Pelayanan Kesehatan Gigi Dan Mulut Tahun 2015-20192015.

(4) Kementrian Sosial. Kementerian Sosial Dalam Angka Pembangunan Kesejahteraan Sosial. Jakarta Badan Pendidikan Dan Penelitian Kesejahteraan Sosial Pusat Data Dan Informasi Kesejahteraan Sosial; 2012.

(5) Saptiwi B, Sukini S, Salikun S, Supriyana S. Aplikasi Program Ukgs Inovatif Irene's Donuts Terhadap Perilaku Pemeliharaan Kesehatan Gigi Dan Mulut Serta Ohi-S Pada Anak Berkebutuhan Khusus (Abk) Di Slb Negeri Semarang. Jurnal Kesehatan Gigi. 2018;2(2):115-9.

(6) Triyanto R. Gambaran Status Kesehatan Gigi Dan Mulut Pada Anak Tunagrahita Usia 12-18 Tahun Di Slb Negeri Widiasih Kecamatan Pari Kabupaten Pangandaran Tahun 2015. Indonesian Oral Health Journal. 2017;2(1).

(7) Wiradona I, Widjanarko B, Syamsulhuda B. Pengaruh Perilaku Menggosok Gigi Terhadap Plak Gigi Pada Siswa Kelas Iv Dan V Di Sdn Wilayah Kecamatan Gajahmungkur Semarang. Jurnal Promosi Kesehatan Indonesia. 2013;8(1):59-68.

(8) Setiari LS, Sulistyowati M. Tindakan Pencegahan Karies Gigi Pada Siswa Sekolah Dasar Berdasarkan Teori Health Belief Model. Jurnal Promkes. 2018;5(1):65-76.

(9) Sularyo TS, Kadim M. Retardasi Mental. Sari Pediatri. 2016;2(3):170-7.

(10) Ratulangi Mh, Wowor Vn, Mintjelungan Cn. Status Gingiva Siswa Tunagrahita Di Sekolah Luar Biasa Santa Anna Tomohon. E-Gigi. 2016;4(2)

(11) Giannasi LC, Matsui My, Freitas Srb, Caldas Bf, Grossmann E, Amorim Jbo, Et Al. Effects Of Neuromuscular Electrical Stimulation On The Masticatory Muscles And Physiologic Sleep Variables In Adults With Cerebral Palsy: A Novel Therapeutic Approach. Plos One. 2015;10(8): E0128959.

(12) Kumin L. Resource Guide To Oral Motor Skill Difficulties In Children With Down Syndrome. Loyal College Of Maryland. 2015.

(13) Sari O, Santy WH. Hubungan Dukungan Keluarga Dengan Tingkat Kemandirian Personal Hygiene Anak Tunagrahita Di Slb Tunas Mulya Kelurahan Sememi Kecamatan Benowo. Jurnal Ilmiah Kesehatan (Journal Of Health Sciences). 2017;10(2).

(14) Goyal S, Thomas BS, Bhat KM, Bhat GS. Manual Toothbrushing Reinforced With Audiovisual Instruction Versus Powered Toothbrushing Among Institutionalized Mentally Challenged Subjects-A Randomized Cross-Over Clinical Trial. Med Oral Patol Oral Cir Bucal. 2011;16(3): E359-64.

(15) Marcon M, Sarti A, Tubaro S. Toothbrush Motion Analysis To Help Children Learn Proper Tooth Brushing. Computer Vision And Image Understanding. 2016;148:34-45.

(16) Afandi M, Chamalah E, Wardani OP. Model Dan Metode Pembelajaran Di Sekolah Perpustakaan Nasional Katalog Dalam Terbitan (Kdt); 2013.

(17) Kemenkes. Pedoman Usaha Kesehatan Gigi Sekolah (Ukgs). Jakarta: Kementerian Kesehatan Ri; 2012.

(18) Ramayumi R, Nurdin AE, Nurhajjah S. Karakteristik Penderita Retardasi Mental Di Slb Kota Bukittinggi. Majalah Kedokteran Andalas. 2015;37(3):181-6.

(19) Kurniawan YI, Dwiyatmika W. Aplikasi Diagnosa Retardasi Mental Pada Anak. 2017

(20) Jaelani B. Metode Drill Bermedia Video Terhadap Keterampilan Bina Diri Anak Tunagrahita Ringan. Jurnal Pendidikan Khusus. 2014;4(1)

(21) Liu Z, Yu D, Luo W, Yang J, Lu J, Gao S, Et Al. Impact Of Oral Health Behaviors On Dental Caries In Children With Intellectual Disabilities In Guangzhou, China. International Journal of Environmental Research And Public Health. 2014;11(10):11015-27. 